\title{
Research
}

\section{Beyond Forest Cover: Land Use and Biodiversity in Rubber Trail Forests of the Chico Mendes Extractive Reserve}

\author{
Jacqueline M. Vadjunec $^{1}$ and Dianne Rocheleau ${ }^{2}$
}

\begin{abstract}
Among the strategies to promote sustainable tropical forest development around the world, the Federal Extractive Reserve System of Brazil is widely cited as an exemplary model. It is designed to protect rubber tapper communities, their forests, and their livelihoods while preventing deforestation and conserving biodiversity. In response to changing markets and policies, rubber tappers in the Chico Mendes Extractive Reserve have recently diversified production to include market agriculture and cattle production, precipitating deforestation in the reserve, with the implication of increased ecological degradation compared to the extraction of nontimber forest products (NTFPs). Our remote sensing and forest inventory analyses yield different insights about the environmental consequences of distinct land-use mixes in two extractive communities, one of which emphasizes cattle and the other, NTFPs. Remote sensing results show a predictably greater impact on forest cover in the cattle-oriented community. This preliminary study is based on nested household- and community-level forest inventory and biodiversity analyses in two communities. Surprisingly, we found higher tree biodiversity in the rubber trail forests of the cattle-oriented community, and significantly lower tree species richness, tree density, total basal area, and number of trees of commercial size in the same land-use unit in the NTFP-focused community. Land-use surveys indicate lower levels of game consumption and hunting in the cattle-oriented community, and strong support for the development of sustainable timber extraction in both communities. The distinct type and degree of forest impact in the two communities exposes the problem of single-impact assessment as the sole means of performance and categorical land-use prohibitions as an effective mode of regulation in conservation areas.
\end{abstract}

Key Words: biodiversity; ecological monitoring; extractive reserves; land use; livelihood; tropical deforestation

\section{INTRODUCTION}

The state of Acre, in western Brazil, features prominently in the environment and development debate in the tropics. It retains $90 \%$ of its forest cover intact (Vianna 2004), 14\% of its territory in protected status, and has been the site of a historic movement to defend forest communities and livelihoods. Since the 1999 election, the progressive "forest government" has emphasized sustainable development, including nontimber forest production (NTFP) within reserves and other protected areas (Kainer et al. 2003). However, pre-existing markets and infrastructure, a legacy of prior policies and ranching subsidies, make cattle ranching the most profitable current option for smallholders in Amazonia (Pacheco 2005). Between 1990 and
2003, Acre had the second highest growth rate of cattle in Brazil (Barreto et al. 2005).

The tension between cattle ranching and NTFP extends back to the 1970s, when Chico Mendes, Wilson Pinheiro, and others led rubber tappers in a struggle to protect their forest holdings from largeholder cattle ranchers. The campaign, and the assassination of Mendes in 1988, led to the creation of Federal Extractive Reserves in 1990, part of a larger program to protect the forests and peoples of the Brazilian Amazon. The Chico Mendes Extractive Reserve (CMER) is one of the first and the most iconic of the 34 Federal Extractive Reserves. The state holds the title to the land, whereas the community holds the concession for its use. The model aims to preserve the extractivist 
communities and land-use systems, as well as the surrounding forest cover and biodiversity (Ruiz Murrieta and Pinzón Rueda 1995, Ministério do Meio Ambiente 2004).

The extractive reserve system is widely cited as a promising model of sustainable development that limits forest clearing (Allegretti 1990, Fearnside 1990, Schmink and Wood 1992), prevents or contains forest fires, and protects biodiversity (Pinard 1993, Nepstad et al. 2006). However, several researchers question the economic, social, and environmental sustainability of the extractive reserve model (Hecht and Cockburn 1990, Browder 1992, Homma 1993) and express doubts about biodiversity conservation in working forest reserves (Terborgh 1999) and community-based parks (Moegenburg and Levey 2002). Since the mid-1990s, extractivists face ongoing economic hardship brought on by unstable rubber prices, deregulation of processed latex imports, and the cessation of federal subsidies to the rubber trade. Many extractivists have diversified their production systems to include market-oriented agriculture such as beans, rice, and manioc crops, and cattle production, precipitating deforestation (Gomes 2001) and problems with fire (Brianezi 2005).

Sustainability and its measures and monitoring mechanisms are not clearly defined within the CMER, aside from specific rules on the limits of forest clearing and protection of key extractive tree species (Reserva Extrativista Chico Mendes: plano de utilização, http://www.ibama.gov.br/resex/cmendes/ plano.htm; IBAMA 2003). For example, the CMER use plan sets allowable maximum limits of deforestation at $10 \%$ of the total area of the household colocação (individual homestead), which in practice is measured and generally monitored on the community level. Not surprisingly, performance assessment has focused largely on satellite imagery detection of forest cover change (Sassagawa 1999), which highlights the impacts of the cattle-oriented communities. In Brazil and beyond, performance evaluation of conservation and management practices in forest reserves has followed two distinct approaches, with few exceptions (Uhl et al. 1997, International Forestry Resources and Institutions 1998, Berkes and Folke 2002, Tucker and Southworth 2005, Sears et al. 2007). Social evaluations employ questionnaires at household scale and/or rapid appraisals at community scale (Margoluis and Salafsky 1998). Environmental evaluations rely on one of two basic methods: remotely sensed imagery assessments of the proportion and persistence of forest cover as indicators of success (NaughtonTreves et al. 2005), as in the case of the CMER; and labor-intensive, forest ecology and biodiversity surveys of small areas to achieve precise results about specific sites. This last method often uses a single index or criterion (Buckland et al. 2005), whereas managers require information on multiple ecological and social criteria in relation to household land-use practices (FETACRE 2003).

In this preliminary study, we compare two distinct measures of forest sustainability and quality. We use forest inventories and interview data from two CMER communities that have contrasting livelihood strategies and associated land-use practices in mixed land-use mosaics. One community emphasizes cattle-based livelihoods; the other emphasizes NTFP extraction. The data collection, results, and analyses address two main hypotheses. The discussion and conclusions also consider related implications for policy, management, and monitoring of the sustainability of a tropical forest habitat and local livelihood. The hypotheses apply to current conditions and practices in the CMER, specifically in these two communities, and do not imply a universal application by land-use category: (1) At community level, a livestockfocused livelihood strategy has a greater impact on overall forest cover, whereas an extractivist livelihood strategy has a greater impact on biodiversity, composition, and structure within active rubber trail forests; (2) Different livelihood and land-use trajectories at community levels have distinct impacts on active rubber trail forests with respect to forest cover, structure, and composition. Both hypotheses have implications for forest sustainability and conservation elsewhere in the tropics, as well as for methods of monitoring forest change and sustainability under mixed land-use practices.

\section{Study area, communities, and households}

\section{Chico Mendes Extractive Reserve}

The CMER is located in the southeastern corner of Acre, bordering Bolivia and Peru. Established in 1990 , it was one of the first extractive reserves in Brazil and is seen as a model for the entire Federal Extractive Reserve system. The CMER comprises 970,570 ha and spans five municipalities: Assis 
Brasil, Brasiléa, Xapuri, Sena Madeira, and Rio Branco. As of the last census, there were just under 2000 families in 46 different rubber tapper communities in the reserve (Feitosa 1995).

The reserve receives an average annual rainfall of $2200 \mathrm{~mm}$ and has a marked dry season from May to August and an average temperature of $26^{\circ} \mathrm{C}$. The topography is slightly to moderately undulating, and the elevation varies between 100 and $300 \mathrm{~m}$. Eutrophic and dystrophic soils dominate in the reserve and are considered viable for agriculture under "good management practices" (Governo do Estado do Acre 2000). Most (73\%) of the reserve is classified as open tropical forest $(<40 \%$ closed forest cover), and the remainder $(27 \%)$ as dense tropical forest (> $40 \%$ closed forest cover; RadamBrasil 1976, Feitosa 1995). The tree species diversity in the region is considered high for tropical forests, with more than 3000 species identified and new species cataloged monthly (New York Botanical Garden, Floristics and economic botany of Acre, Brazil, http://www.nybg.org/bsci/acre/title. html). We focused on changes in dense tropical forest portions of the reserve, which are both high in NTFP species and intensively used and managed by households.

\section{Community and households}

Reserves are divided into seringais (traditional rubber estates) and composed of colocações (individual homesteads). The colocação is a fluid property system, defined by its trees (extractive resources), rather than by fixed polygons in Euclidean space. A typical colocação is approximately one hour's walk from the nearest neighbor and contains the rubber tapper family's house and other buildings, patio garden, agricultural plot, and pasture, as well as rubber trail forests (forest extractive units) and the surrounding forest matrix, all of which is within the household's property (Fig. 1). The properties were originally allocated based on the number of estradas de seringa (rubber trail forest units). In 1990, each household on the new reserve was allotted at least three rubber trail units. On average, it takes 100125 ha of forest to create a single rubber trail. Our study was conducted within the immediate rubber trail forest unit, each of which represents an area of 12 ha of mature forest consisting of an extractive forest strip roughly $10 \mathrm{~m}$ wide on either side of the central footpath, $6 \mathrm{~km}$ in length. The rubber trail units, which represent approximately $10 \%$ of the total forest area, are purposely carved out of the surrounding forest in each household's colocação to maximize encounters with the most lucrative extractive species. Therefore, the reserve and forest as a whole are entirely subdivided into an invisible patchwork of colocação properties, with a forest matrix, rubber trail forest units, and the other mixed household land-use units.

Increasingly, rubber tappers buy and sell the use rights to rubber trails. The smallest colocação in the sample had two rubber trails, whereas the largest had twelve. This shuffling of trails among households permits those who rely heavily on extractive activities greater access to rubber trails beyond their original holdings. It also allows those relying on nonextractive activities to expand their pasture and cropland onto additional holdings without breaking the $10 \%$ deforestation rule on their original colocação (Ankerson and Barnes 2004).

In response to conservation programs and falling rubber prices, reserve households have increasingly turned to agricultural activities. For the most part, the reserve-wide rules do not currently allow commercial timber harvest for sale, yet they allow each household to deforest $2 \mathrm{ha} / \mathrm{yr}$ to plant staple crops. Some rubber tappers argue that agriculture encourages deforestation and sustains poverty. They press for the right to manage their forests for selective timber extraction to earn cash income for food and other needs.

\section{Study sites}

We called the two study sites community A and community B. The two seringais share similar geographical characteristics, with mixed land use and significantly different livelihood and related land-use emphases: NTFP and cattle production. They are located in close proximity in the same municipality and have similar access to the nearest town (market). They share similar histories in the rubber tapper's movement, access to the same government programs, and similar institutions governing access to land and resources. The two communities are also similar in terms of their colocação size, mean slope, elevation, and basic soil indicators at the $\mathrm{A}$ and $\mathrm{B}$ horizons (Table 1).

Community $\mathrm{A}$ is smaller in area and population than community B. These discrepancies have little effect on the forest cover and diversity comparisons because colocação size and population density are 
Fig. 1. Example of a colocação, or individual homestead. Black lines represent dirt roads connecting households; blue lines represent waterways; purple lines represent a household's rubber trails. The entire forest on the reserves is divided into household forest properties. It is allocated based on the number of rubber trails per property. Each trail is cut to maximize encounters with rubber and Brazil-nut trees and requires on average 100-125 ha of forest to create one forest extractive trail; the rubber trail unit itself accounts for approximately $10 \%$ of the forest. In the extractive reserve forest landscape, all forest is under active management and use. The sketch map is not drawn to scale, but is representative of a typical household's landholdings.

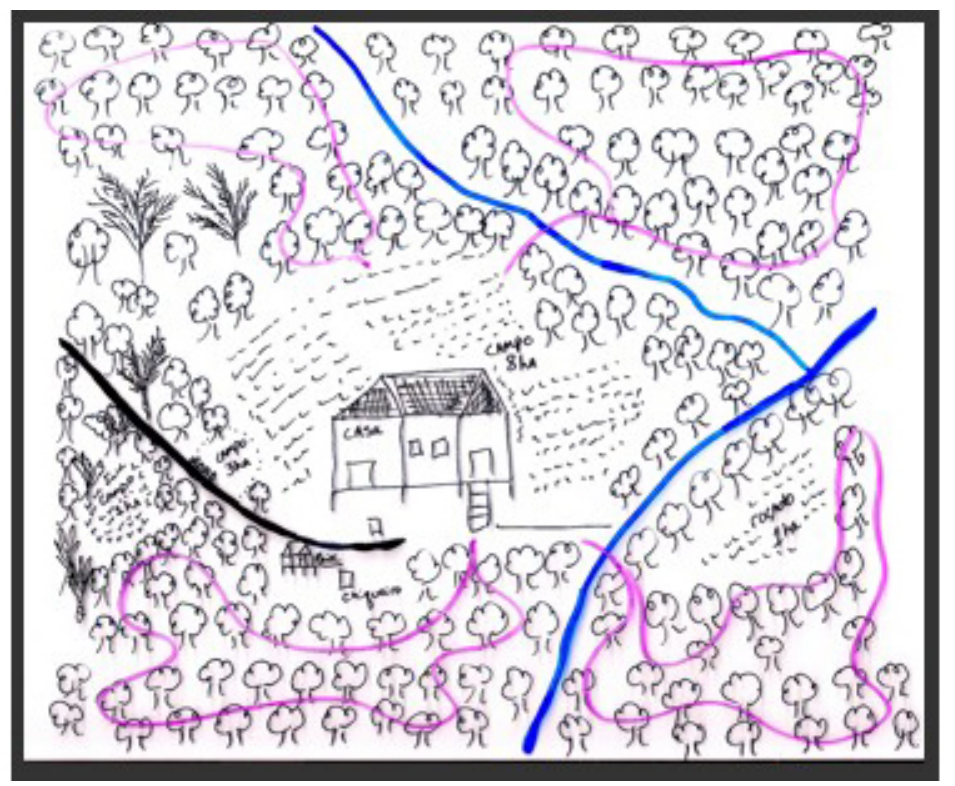

roughly the same in both communities, and all forested lands in both communities belong to reserve households.

External agencies view community A as "full of cattle" and community B as focused on NTFP projects. Household data (Table 2) indicate that community $\mathrm{B}$ is more involved in extractive activities: collection of açai berries and latex, legal timber extraction for household use, and hunting. Reports from local authorities and key-informant interviews also indicate sporadic illegal extraction of commercial hardwoods in community B.

Whereas an equal proportion of households in the two communities participate in cattle production $(93.3 \%)$, the scale of cattle ranching, the amount of pasture, and the total area deforested per household differ markedly (Table 3). Community A has roughly twice the amount of cattle per household
(14.20 vs. 7.47 ), with about $60 \%$ more pasture and total area deforested than community B.

The NTFP-oriented community B reports a $30 \%$ higher participation rate in hunting game than does community A. The five most hunted species include: Paca (Agouti paca), Amazon Blue-fronted Parrot (Amazonia ochrocephala), Tinamou (Crypturelius sp.), Brazilian Agouti (Dasyprocta sp.), and Whitelipped Peccary (Tayassu pecari). Average game consumption per household in the NTFP-oriented community (Table 4) is double that of the cattlefocused community, consistent with Amazonian studies linking growth in livestock production by extractivists to decreased hunting (Minzenberg 2005). Community A reports either increased or stabilized game populations within the last 10 years, whereas community B reports declines, although there are no numerical baselines with which tojudge these. The concentration and fencing of pastures, 
Table 1. Physical characteristics of the two study sites. Values are the mean (SD).

\begin{tabular}{lcc}
\hline \hline Physical characteristic & $\begin{array}{c}\text { Community A } \\
(\mathrm{n}=15)\end{array}$ & $\begin{array}{c}\text { Community B } \\
(\mathrm{n}=15)\end{array}$ \\
\hline Colocação size (ha) & $429(2.72)$ & $469(2.76)$ \\
Slope (degrees) & $7.00(5.74)$ & $7.40(7.40)$ \\
Elevation (m) & $248(43.6)$ & $223(75.5)$ \\
Depth of humus layer (cm) & $1.71(0.56)$ & $1.51(0.09)$ \\
Dominant soil texture of horizon A & Sand & Sand \\
Dominant soil texture of horizon B & Clay & Clay with few isolated patches of loam \\
\hline
\end{tabular}

typical of community A, reduces encounters between cattle and predators and presumably reduces hunting to control predators such as the spotted panther (Panthera onca; J. M. Vadjunec personal observation).

These communities are not polar opposites; they constitute two distinct, complex mixes of livelihood strategies and land-use practices. Both communities participate in subsistence and commercial agricultural production and Brazil-nut collection. Community A increasingly emphasizes cattle, and community B continues to emphasize NTFP as a primary source of income. Community A has larger amounts of concentrated, shared and fenced pasture, whereas pastures in community B tend to be smaller, patchy, and dispersed.

\section{METHODS}

\section{Research design and site selection}

Given the limitations of available resources and logistic feasibility, the research design for this preliminary study sacrificed replication of community sites for more rigorous sampling, better detail, and more variables at the sample plot and household (colocação) level. This allowed for a relatively complete sample of the rubber trail forest holdings within the communities, with approximately $50 \%$ of all household-level holdings included in the sample, and for in-depth land-use and livelihood surveys with the household members in each of the rubber trail forest holdings sampled. The first author resided with community members during both the forest inventory and the in-depth forest livelihood and forest land-use interviews conducted at household level. Data from additional key informant interviews on land use and management at the community level, as well as attendance and discussions at formal community and other organizational meetings, also informed the interpretation of the forest inventory and household interview data.

The two communities selected were already included in previous comprehensive social and land-use surveys (Vadjunec 2007), as well as landuse studies using remotely sensed imagery of forest cover (Vadjunec et al. in press). This prior information allowed for an informed choice of the two representative communities for a comparison of forest inventory and interview data from two sites with contrasting livelihood strategies and associated land-use practices in mixed land-use mosaics. The selection of communities with similar biophysical characteristics, forest types, and history, up until the recent divergence in livelihood strategy, also reflected the judgment of botanists and other scientists at the Federal University of Acre, Brazil, based on expert knowledge and extensive field experience in the CMER. 
Table 2. Percentage of households in each community participating in specific land-use activities. $\dagger$

\begin{tabular}{lcc}
\hline \hline Land-use activity & $\begin{array}{c}\text { Community A } \\
(\mathrm{n}=15)\end{array}$ & $\begin{array}{c}\text { Community B } \\
(\mathrm{n}=15)\end{array}$ \\
\hline Brazil-nut collection & 100 & 100 \\
Latex collection & $11.8^{*}$ & $37.5^{*}$ \\
Açai collection & $10.0 \ddagger$ & $40.0 \ddagger$ \\
Hunting & $70.0^{*}$ & $100^{*}$ \\
Timber (household use) & $70.0^{*}$ & $95.0^{*}$ \\
Agriculture & 100 & 100 \\
Small livestock§ & 100 & 93.3 \\
Cattle production & 93.3 & 93.3 \\
\hline
\end{tabular}

$* P<0.05$.

$\dagger$ The household information used was informed by community and household surveys as part of a larger study conducted by J. Vadjunec in collaboration with C. V. Gomes (see Vadjunec 2007).

$\ddagger P<0.10$.

§Small, domesticated livestock such as chickens, ducks, goats, sheep, and pigs.

\section{Satellite imagery analysis of forest cover change}

Landsat 5-TM and 7-ETM+ satellite imagery data were used to analyze the amount and rates of deforestation at the pixel level during the dry season (June to September) for 1986, 1996, 1999, and 2003. All image processing was carried out on the footprint level, which is the standard extent of coverage for a single LANDSAT scene, for Row 02/Path 67. Preprocessing included radiometric calibration and atmospheric correction (Green 2001). The 2003 image was georeferenced using ground-control points taken using a GPS along roads and waterways. Each of the remaining images was then georeferenced using a nearest-neighbor resampling alogorithm, with a root mean square error of $<0.5$ pixels.

Images were classified using an unsupervised/ supervised approach (Vadjunec 2007). Each image was divided into 100 classes using the ISODATA module in ERDAS Imagine. Ground reference data gathered in the field were used to guide decisions on how to collapse the 100 classes based on identified land-cover categories and their spectral separability. Six final classes were used: mature forest, secondary forest, agriculture or pasture, high-density urban, water, and cloud or shadow, with an accuracy of $84.7 \%$ for the 2003 image. The accuracy assessment was performed using the ERRMAT module in IDRISI Kilamanjaro. A holdout sample of training sites that were taken in the field was used, representing all geographic quadrants of the footprint and at least 90 pixels for each class.

We used only two cover classes for this study: forest and nonforest. A three-by-three kernel filter was applied to clean up the images, thus eliminating incidents of single pixel deforestation and focusing instead on larger areas that are more likely to be deforested for agriculture or pasture formation. Transition matrices were created for 1986-1996, 
Table 3. Comparison of mean (SD) household values for specific land-use variables.

\begin{tabular}{lcc}
\hline \hline Land-use variable & $\begin{array}{c}\text { Community A } \\
(\mathrm{n}=15)\end{array}$ & $\begin{array}{c}\text { Community B } \\
(\mathrm{n}=15)\end{array}$ \\
\hline Total number of cattle & $14.2(13.49)^{*}$ & $7.5(7.62)^{*}$ \\
Area in pasture (ha) $\dagger$ & $8.53(5.57)^{*}$ & $5.23(2.86)^{*}$ \\
Total deforested area (ha) $\neq$ & $20.67(11.94)^{*}$ & $13.00(5.20)^{*}$ \\
\hline
\end{tabular}

$* P<0.05$.

$\uparrow$ Actual cleared pasture in 2003-2004

\$All deforested land, including successional growth.

1996-1999, and 1999-2003. Once forest cover was lost, it could only return to a secondary forest class. The result is a final image calculating the cumulative rates and location of cover change within both communities through the three time intervals.

\section{Field inventories of biodiversity in household rubber trail forests}

Forest surveys of structure and composition capture detailed, ground-level information that can be used to calculate biodiversity indices and total basal area. Two teams of six to eight people each, including the first author, agronomists, botanists, and foresters, carried out the forest inventory during the dry season in April and May of 2005. The teams trained together in the field to standardize their methods.

The research design for the inventory focused on household rubber trail forests, based on the size of the colocações, financial and environmental constraints, and our emphasis on land-use impacts in rubber tapping zones within the forest. Prior studies have used rubber trails as "natural transects" to represent the forest as a whole (Alechandre da Rocha 2001, Kageyama et al. 2004). In contrast, we treated the rubber trail forest as a distinct land-use unit and sampled rectangular plots at fixed intervals along alternating sides of the central path to represent the rubber trail forest specifically, as an extractive forest unit and the most accessible intensively used forest land-use unit within the larger forest holdings. The survey characterized the species richness, abundance, and size classes of trees within the rubber trail forest to document the impact of household- and community-level use, although this was limited by the assumptions of similar forest cover, structure, and diversity prior to the divergence in livelihood strategies.

During previous household and community mapping exercises (Vadjunec 2007), the number and length of actively maintained individual rubber trails were tabulated. For "actively maintained," we distinguished between rubber trails that were completely abandoned by the landholder and rubber trails that are still cleaned and maintained annually for rubber tapping and/or the collection of Brazil nuts and other nontimber forest products. A stratified sampling technique, based on the previously mapped number and length of trails per household, was used in 15 colocações within each of the two communities $(n=30)$. Overall, 120 plots of $10 \times 25 \mathrm{~m}\left(250 \mathrm{~m}^{2}\right)$ were inventoried, representing the recommended sample size of $1.5 \%$ of the total forest area (Oliveira and Sant'anna 2003), in this case based on the total length and average width of rubber trail forest units. Plots were located every $500 \mathrm{~m}$, parallel to the walking trail, alternating to the right and left. To avoid edge effects, the first transect began $100 \mathrm{~m}$ from the trail's entrance. The research team identified all tree species with a diameter at breast height $(\mathrm{dbh}) \geq 10 \mathrm{~cm}$ and measured the height and dbh of each individual tree. 
Table 4. Mean (SD) consumption of the top five hunted game animals (2003-2004), and changes in animal populations over the last ten years as reported by a random subsample of households.

\begin{tabular}{|c|c|c|c|c|}
\hline \multirow[b]{2}{*}{ Species } & \multicolumn{2}{|c|}{ Community A $(\mathrm{n}=10)$} & \multicolumn{2}{|c|}{ Community B $(\mathrm{n}=10)$} \\
\hline & $\begin{array}{l}\text { Annual consumption } \\
\text { per household }\end{array}$ & $\begin{array}{l}\text { Population } \\
\text { change }\end{array}$ & $\begin{array}{l}\text { Annual consumption } \\
\text { per household }\end{array}$ & $\begin{array}{l}\text { Population } \\
\text { change }\end{array}$ \\
\hline Paca (Agouti paca) & $7.7(5.5)$ & + & $14.1(11.3)$ & - \\
\hline $\begin{array}{l}\text { Amazon Blue-fronted Parrot } \\
\text { (Amazonia ochrocephala) }\end{array}$ & $0.7(1.7)$ & + & $5.5(9.9)$ & - \\
\hline Tinamou (Crypturelius sp.) & $5.0(5.9)$ & no change & $5.0(3.1)$ & - \\
\hline Brazilian Agouti (Dasyprocta sp.) & $2.0(3.1)$ & + & $4.4(2.8)$ & - \\
\hline $\begin{array}{l}\text { White-lipped Peccary (Tayassu } \\
\text { pecari) }\end{array}$ & $0.2(0.4)$ & no change & $3.4(3.5)$ & - \\
\hline Average game consumption & $15.7(10.7)$ & no change & $32.4(18.8)$ & - \\
\hline
\end{tabular}

Other data gathered included percent tree cover, slope, elevation, basic soil characteristics at the A and B horizons such as texture and Munsell color; the geographic coordinates were obtained using GPS (International Forestry Resources and Institutions 1998). All species were identified in the field by professional field botanists who had received extensive training by the New York Botanical Garden in conjunction with the Universidade Federal do Acre and who had experience in conducting the Acre Forest Inventory (EMBRAPA 2000, Oliveira and Sant'anna 2003) and other research studies (Euler 2006).

Several measures of diversity, including the Margalef, Shannon, and Simpson indices, and broken-stick and log-normal goodness of fit tests, were calculated to evaluate and compare the species richness, abundance, composition, and distribution of trees in extractive forest units in the two communities (seringais; see Magurran 2004 for formulas). Because many of these indices assume equal area sampled, data from an equal number of forest plots were randomly subsampled from each household rubber trail holding (colocação) to calculate these indices $(n=42$ each, 84 in total, with the number of plots per household proportional to the total length of rubber trail forest in each).
Species-area curves were constructed using Biodiversity Pro software (McAleece 1997). Species diversity estimates beyond the observed data were calculated using Chao 1 and Jackknife models in Biodiversity Pro software to compare estimates between communities. These estimates represent best practice for sample plot data in diverse tropical forests with high numbers of rare species and singletons (Magurran 2004). The distributions of species rank and abundance data were also tested for fit to theoretical distributions of log-normal $\left(\log _{10}\right)$ and broken-stick models using Biodiversity Pro. To characterize stand volume and age, average basal area per species was calculated (units: $\mathrm{m}^{2} / \mathrm{ha}$ ) at the colocação level and averaged for the two communities (West 2004). Given that spatial autocorrelation is one of the major concerns for statistical validity in a case with a comparison of two sites and with a nested research design, the data from each community, for each of the reported variables, were tested for spatial autocorrelation. The means of variables aggregated at household (colocação) level, which were treated as dependent variables, were each tested through multiple regression with household-level location values (GPS-derived UTM Northing and Easting values and their products), which were treated as independent variables. 


\section{RESULTS}

\section{Forest change analysis}

A transition matrix of forest and nonforest categories between 1986 and 1996, 1996 and 1999, and 1999 and 2003 reveals differences in the amounts and rates of deforestation between the two communities (Fig. 2). Community A had already cut $8.26 \%$ of its forest by 2003 , with an average annual rate of $0.38 \% / y r$ throughout the 18 -year period of study. In contrast, community B had cut only $3.83 \%$ of its forest by 2003 , and its average annual deforestation rate was $0.20 \% / y r$. Community A had a significant increase in the rate of deforestation in the last period of analysis, jumping to $0.52 \% / y r$, whereas community B's rate stabilized at $0.23 \% / \mathrm{yr}$.

\section{Forest inventory and biodiversity results}

In the 84-plot subsample in the two colocações, 1023 tree stems were counted and 218 tree species identified (Appendix 1). The canopy height and the diameter of emergent trees were similar in both communities (Table 5), suggesting similar site productive capacity, forest productivity, and environmental characteristics in the two communities (West 2004). Although there is no before and after comparison, the comparison of these otherwise similar sites showed significant differences between specific structure and diversity measures, i.e., percent crown cover, number of trees per plot, number of species per plot, and total basal area, which often serve as indicators of different use and management practices. These results may reflect differences in the use and management of rubber trail forests in the two communities.

The summary species abundance and rank data from the sample plots fit the broken-stick model in both cases $(p<0.001)$. The data did not fit the log-normal model $(p>0.10)$ in each of the two communities (Table 6), indicating a relatively even mix of abundant species, as well as a large number of rare or unique species. The species-area curves (Table 7, Fig. 3A) tend toward the asymptote, but indicate that not all species were sampled. The uniqueness plot (Fig. 3B) indicates that the species observed include most of the species in the areas sampled, giving an adequate, if not perfect, estimate of species richness. Given the high incidence of singletons (single individuals of a given species), which is common in tropical forests, along with the failure to reach an asymptote, we also used the jacknife (Fig. 3C) and Chao 1 estimates, both of which increased the estimate of species richness (see Magurran 2004 for more details). Multiple regression analyses showed no significant correlation in either community between the independent location variables and each of the dependent forest structure and tree species composition variables. The data from rubber trail forest sample plots, aggregated to the household (colocação) level of rubber trail holdings, are independent and allow the use of statistical tests that assume independent samples. Regardless of the species observations or estimates used, all diversity indices differ significantly at the 0.05 level between the two communities (Table 7). Community A has higher species richness in rubber trail forests than does community B, and this relationship also holds for the Margalef, Shannon, and Simpson diversity indices.

The substantial overlap in species between the communities is reflected in a correlation of $86.24 \%$, with 71 species ( $32.57 \%$ of the total community) distinct to community A, 62 species $(28.44 \%$ of the total community) distinct to community $\mathrm{B}$, and 7 of the 10 most dominant species in common (Table 8). The difference in basal area between the communities is roughly $25 \%$, which is even more pronounced than the difference in species richness and crown cover (20\%). Community A has significantly more stems per plot and is a much denser forest with a higher total basal area of 54.80 $\mathrm{m}^{2} / \mathrm{ha}$, compared to $40.63 \mathrm{~m}^{2} / \mathrm{ha}$ in community B. Although both basal areas suggest mature forests according to tropical standards (Mori et al. 1983, Moran and Brondizio 1998), that of community A is markedly higher than that of community B.

The high incidence of singletons makes the diversity indices in these forests sensitive to the harvesting of even small numbers of trees (Groom et al. 2006). Also, some species such as Brazil nut, cedar, and intaúba are more likely to be harvested in high numbers based on their value for local use and sale. An analysis of the most popular commercial timber species in Acre (Table 9) indicates that even though community B appears to have a greater number of commercially valuable hardwood trees per unit area (approximately 152 trees/ha in B vs. 123 trees/ha in A), community A has a greater number of commercial hardwood species $(27$ species/ha in A vs. 23 species/ha in B). Although a greater proportion of trees in community $\mathrm{B}$ are species of 
Fig. 2. Land-cover transition caused by deforestation for 1986-2003.

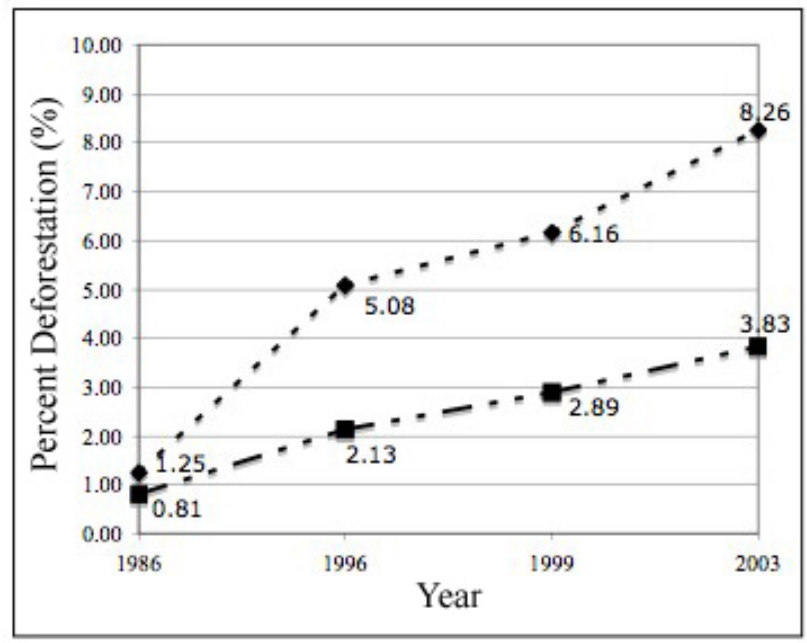

known commercial potential $(27.73 \%$ in $\mathrm{B}$ vs. $18.95 \%$ in $\mathrm{A}$ ), community $\mathrm{A}$ has a greater number of actual commercial size $(\mathrm{dbh}>50 \mathrm{~cm})$ per unit area: 30 trees/ha, or $24.4 \%$ of commercial stems in all sample plots. Community $\mathrm{B}$, with a greater number of commercial trees present per unit area, has fewer of commercial size: 16 trees/ha, or $10.5 \%$ of the commercial tree stems in all sample plots.

\section{DISCUSSION}

Much of the literature cites medium- and largeholder cattle ranchers as most responsible for deforestation in Amazonia (Pacheco 2005). However, recent studies suggest that smallholders, on or off reserves, are responsible for as much as $62 \%$ of the new deforestation in Acre (Elia 2005, Barreto et al. 2006). Smallholders have not deforested a greater area than largeholders, but largeholder pasture development is slowing because it is increasingly constrained by the expansion of protected areas in the region. Cattle and pasture are expanding on reserves as NTFP extractivists turn to more intensive land uses. Many CMER households view cattle as the least risky and highest return activity available to them under current conditions. Whether it remains so depends on economic forces beyond the reserve and the alternative activities legally open to CMER communities.
With $>8 \%$ of the area deforested, and recent average deforestation rates exceeding $0.50 \% / y r$, cattleoriented community A may be considered on the high end of overall deforestation rates in Acre $(<$ $1 \% / y r$; Instituto Nacional de Pesquisas Espacias 2005). NTFP-oriented community B has reached a deforestation rate of $0.23 \% / \mathrm{yr}$ and cumulative total deforestation of 3\%, which is the pan-CMER average per seringal (Sassagawa 1999). Deforestation in the CMER notwithstanding, there is good reason to think that the natural and environmental consequences of it differ from largeholder deforestation (Denevan 1992, Glaser and Woods 2004). The landscape matrix of smallholder land cover, if it can be retained, is heterogeneous, with patches of forests in different stages of successional growth. Recent research shows that over half of this area in succession in the CMER is either recut for use in swidden agriculture or, increasingly, is planted with tropical kudzu and left to fallow for a short period before returning to pasture. Some successional forest is permitted to reach stages of advanced secondary growth beyond 20 years (Vadjunec 2007).

Moving from satellite to on-the-ground forest studies reveals another kind of tropical forest change: the reduction in the number of tree species, forest density, and basal area in the community that is more focused on NTFP extraction. This level of analysis points to greater forest disturbance in the 
Table 5. Forest structure at community and household levels, as determined by forest inventory.

\begin{tabular}{|c|c|c|c|c|}
\hline \multirow[t]{2}{*}{ Variable } & \multicolumn{2}{|c|}{$\begin{array}{c}\text { Community total } \\
(\mathrm{n}=42 \text { plots, } \text { area }=1.05 \mathrm{ha})\end{array}$} & \multicolumn{2}{|c|}{$\begin{array}{c}\text { Community-level means (SDs) of household } \\
\text { plot data } \dagger(n=30)\end{array}$} \\
\hline & Community A & Community B & Community A & Community B \\
\hline Predominant height $(\mathrm{m}) \ddagger$ & & & $30.9(3.4)$ & $30.6(3.8)$ \\
\hline Tree diameter at breast height $(\mathrm{cm})$ & & & $27.4(4.9)$ & $26.1(2.1)$ \\
\hline Percent crown cover & & & $41.0(10.0)^{*}$ & $32.0(8.0)^{*}$ \\
\hline $\begin{array}{l}\text { Number of trees with diameter at } \\
\text { breast height }>10 \mathrm{~cm}\end{array}$ & 564 trees/ha & 459 trees/ha & $15.6(1.9)^{*}$ & $13.5(2.2)^{*}$ \\
\hline $\begin{array}{l}\text { Estimated number of rubber trail } \\
\text { trees per household } \S\end{array}$ & 31,742 & 23,629 & & \\
\hline Number of species & 169 & 146 & $13.1(2.0)^{*}$ & $11.0(2.0)^{*}$ \\
\hline Total basal area of trees $\left(\mathrm{m}^{2} / \mathrm{ha}\right)$ & & & $54.8(22.9)^{*}$ & $40.6(15.6)^{*}$ \\
\hline
\end{tabular}

$* P<0.05$, two-tailed t-test at mean plot level.

$\dagger$ Sample plots $250 \mathrm{~m}^{2}$ in size within household rubber trails.

$\ddagger$ Measured as the mean height of the tallest trees in the stand, based on 100 stems/ha (see West 2004).

$\S$ Estimated as trees/ha $\times$ mean hectare in rubber trail forests per household.

rubber trail forests of NTFP-oriented community B, assuming that both communities began with forests of roughly the same age, type, and condition (Table 1). The rubber trail forests of community $B$ ranked lower than those of community A in every measure of current biodiversity and volume, other than the number of individuals of commercial timber species (irrespective of individual size).

For instance, the Brazil-nut tree, a federally protected species, is not only an economically important NTFP species, it is a local favorite in household construction and has been a source of contention between residents and local authorities. Community B has a greater number of Brazil-nut trees (approximately 15 trees/ha vs. 11 trees/ha in community A), but community $\mathrm{A}$ has a greater percentage of both commercial size $(\mathrm{dbh}>50 \mathrm{~cm})$ and old growth $(\mathrm{dbh}>100 \mathrm{~cm})$, typical of the species when it is allowed to grow to maturity (Table 9). Both communities have similar histories of Brazil- nut extraction, with no evidence of enrichment planting, suggesting that the marked imbalance in its size class distribution within community B may follow from differences in timber extraction.

Linked to this example are the possible forest consequences of the reported higher levels of hunting in community $\mathrm{B}$ than community $\mathrm{A}$. Animals and forests are interdependent, particularly in regard to diversity (Terborgh 1999, Carneiro da Cunha and Barbosa de Almeida 2002, Moegenburg and Levey 2002). Community A reports overall increases in game populations, whereas community $\mathrm{B}$ reports decreases. The Brazilian agouti, a large, neotropical rodent hunted to a greater extent in community $\mathrm{B}$, is known to affect the distribution of canopy tree species in the Amazon (Asquith et al. 1999, Silvius and Fragoso 2003). These results suggest that the economic and livelihood constraints placed on traditional NTFP extractivists lead to a greater disturbance of rubber trail forests caused by 
Table 6. Comparison of log-normal and broken-stick species abundance models using chi-square goodnessof-fit tests.

\begin{tabular}{|c|c|c|c|c|}
\hline \multirow[t]{2}{*}{ Variable } & \multicolumn{2}{|c|}{ Community A } & \multicolumn{2}{|c|}{ Community B } \\
\hline & Log-normal $\left(\log _{10}\right)$ & Broken-stick & Log-normal $\left(\log _{10}\right)$ & Broken-stick \\
\hline Chi-square & 3.44 & 29.78 & 1.58 & 19.75 \\
\hline Degrees of freedom & 4 & 3 & 3 & 3 \\
\hline$P$ & $>0.10$ & $<0.001$ & $>0.10$ & $<0.001$ \\
\hline
\end{tabular}

higher rates of selective logging for legal household use, as well as illegal sale, and possibly also related to the ecological consequences of overhunting.

Although the forest structure as a whole appears similar between the two communities, commercially valuable timber species are in very different stages of regeneration. Differences in tree basal area between the two communities, coupled with the distribution of commercial and noncommercial tree size classes among popular timber species in the rubber trail forests (Table 9), suggest differences in forest management, particularly regarding selective timber harvesting. There is much greater diversity and abundance in small size classes across species than in larger trees overall, especially with respect to commercial tree species. The marked difference between the two communities in the proportion of commercial trees of commercial size could be explained by a higher rate of timber off-take of commercial hardwood species and also the local use of Brazil-nut trees in community B. In some instances, stumps were noted, but not quantified, along rubber trails in community B. Household surveys and key informant interviews both indicate a regular, higher rate of timber harvesting for household construction in community B than community A, as well as sporadic selective timber harvesting for illegal and below-market sale in the same community. This may explain both the lower species richness counts and estimates, caused by the harvest of singletons of commercial species, and the lower total basal area, related to the tendency toward smaller trees among commercial species and Brazilnut trees, the larger commercial-size trees having been selectively removed.
Our comparison suggests that the different land-use emphases within extractivist communities have different consequences for forest structure and composition. NTFP-oriented community B maintains proportionately higher forest cover overall, as expected. Cattle-oriented community A, surprisingly, maintains higher biodiversity in its active rubber trail forests than does community B. Based on the average range of total basal area at $25-50 \mathrm{~m}^{2} / \mathrm{ha}$ (Moran and Brondizio 1998:110) for mature forests in Amazonia, both community A $\left(54.8 \mathrm{~m}^{2} / \mathrm{ha}\right)$ and community B $\left(40.6 \mathrm{~m}^{2} / \mathrm{ha}\right)$ undoubtedly maintain very mature, diverse rubber trail forests, with less disturbance in the rubber trail forests of the more cattle-focused community.

Our results indicate that the type and scale of analysis matters in assessing conservation areas, with implications for the criteria and means of monitoring a reserve's environmental performance. Remote-sensing analyses will show more cattleoriented seringais as the primary communities that are clearing mature forests and creating a landscape with larger amounts of open land and secondary vegetation. In contrast, field inventories and household surveys reveal the consequences of a dependence on an extractivist livelihood, and some extractivist activities, on the structure and diversity of rubber trail forests.

This last observation is especially important for CMER and reserve performance throughout Brazil because formal criteria that account for deforestation in terms of both cover and composition have yet to be established. The prevailing paradigm of analysis and monitoring, via 
Table 7. Tree species and abundance characteristics in the two communities.

\begin{tabular}{|c|c|c|c|c|}
\hline \multirow[t]{2}{*}{ Variable } & \multicolumn{2}{|c|}{ Community-level counts and estimates } & \multicolumn{2}{|c|}{$\begin{array}{l}\text { Community-level means (SDs) of household } \\
\text { plot data }(\mathrm{n}=30)\end{array}$} \\
\hline & Community A & Community B & Community A & Community B \\
\hline Number of species in plots & 169 & 146 & $13.1(2.0)^{*}$ & $11.0(2.0)^{*}$ \\
\hline $\begin{array}{l}\text { Number of exclusive species } \\
(\%) \dagger\end{array}$ & $71(32.6)$ & $62(28.4)$ & & \\
\hline Margalef diversity & & & $4.37(0.54)^{*}$ & $3.79(0.56)^{*}$ \\
\hline Simpson index (1/D) & & & $56.10(26.90)^{*}$ & $33.73(20.17)^{*}$ \\
\hline Shannon index $(\mathrm{H})$ & & & $2.48(0.19)^{*}$ & $2.29(0.19)^{*}$ \\
\hline Predicted jacknife & 248.07 & 214.33 & & \\
\hline Predicted Chao 1 & 295.17 & 257.36 & & \\
\hline
\end{tabular}

$* \mathrm{P}<0.05$, two-tailed t-tests at the mean plot level.

$\dagger$ As a percentage of all species found in both communties $(n=218)$.

satellite, amplifies the importance of one form of forest change, i.e., deforestation, over changing forest volume and composition. It is noteworthy that biodiversity is increasing in status relative to deforestation among some global research and application communities (Bruner et al. 2001, Diversitas 2002, Ferraz et al. 2003), and the assessment of this factor will surely require finetuned surveys. Assessment of reserve performance must increasingly involve different types and scales of analysis that address multiple criteria linked to various livelihood logics and land-use activities, as well as other social criteria (e.g., Berkes and Folke 1998, 2002, Castillo and Toledo 2001, Berkes and Adhikari 2006, Sears et al. 2007, Berkes 2008).

This raises implications for the planning, operating, and monitoring of extractive reserves in Brazil. The initial promise and potential of NTFP extractivism has not yet led to the economic development necessary for sustaining local livelihoods (Uhl et al. 1997), in part because of the initial withdrawal of subsidies for latex and other extractive products. Many extractivists have turned to more intensive land uses. Community A has expanded its pasture to increase income, and households without cattle in community B may be forced to harvest timber illegally for very low prices to deal with health and other emergencies. Some local authorities and environmental nongovernmental organizations categorically reject cattle and timber extraction in the CMER and refuse to provide extractive reserve residents with technical and regulatory support for either activity. In turn, many households in both communities favor new rules to allow both sustainable cattle production and selective timber harvest. Selective hardwood extraction experiments have recently started within the reserve, and timber extraction has occurred in extractive settlement projects outside the CMER and in other regions, with some success (Veríssimo et al. 2002, Stone 2003). Many households in community A state that they would keep fewer cattle if they could selectively harvest high-value timber legally for part of their regular cash income.

Both communities are losing forest to marginally productive cropland under the project formula that privileges food crops and NTFP over cattle or timber harvest. Encouraging extractivists to deforest 2 ha/ 
Fig. 3. Observations and estimates of species richness in two communities.

\section{Community A}

a) Observed Species Area Curve

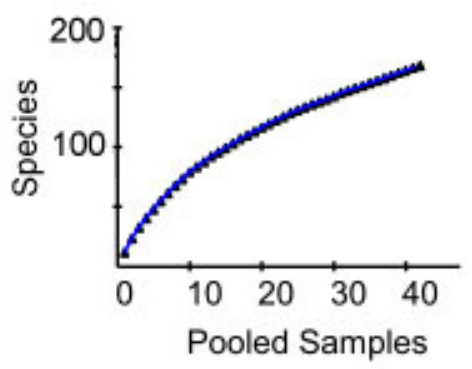

b) Observed Uniques

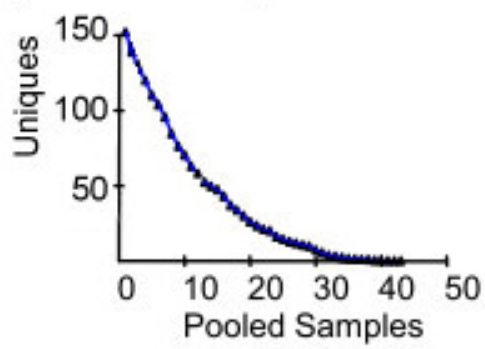

c) Predicted Jacknife

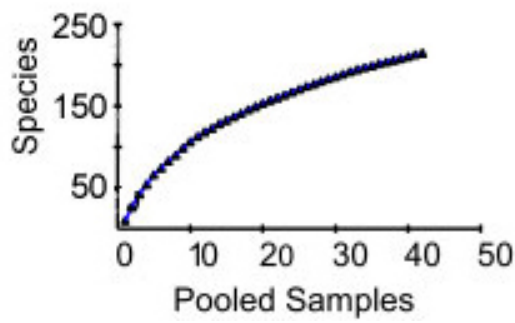

Community B
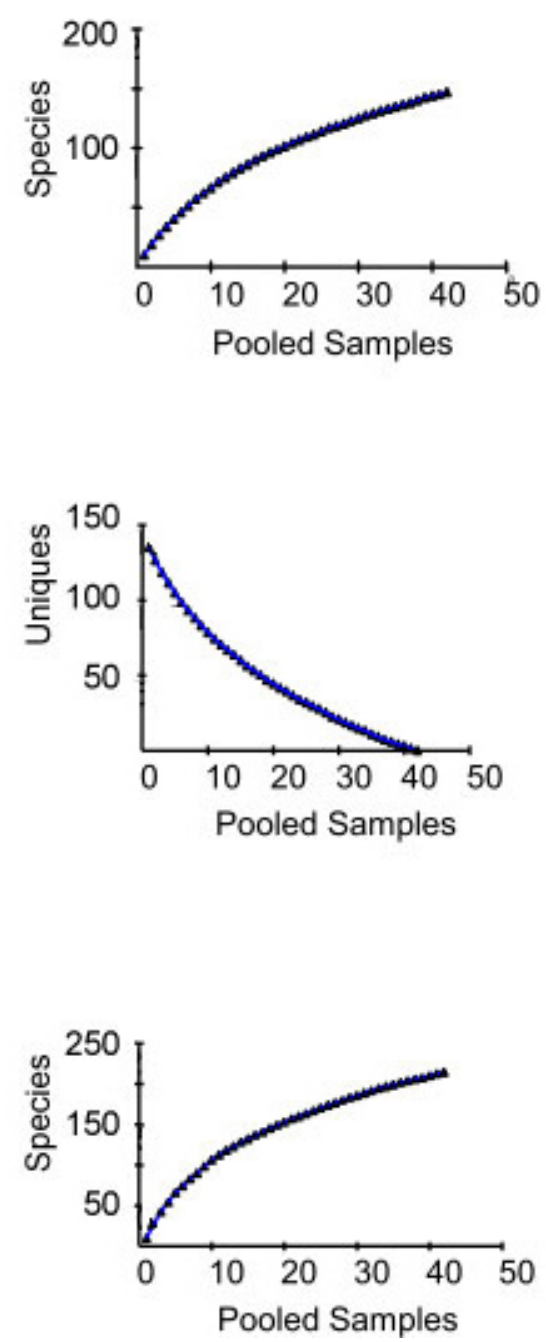

yr for agriculture, yet not allowing legal, selective timber extraction, makes little sense to many of the reserve's residents. As one official noted, "How and why are 2 ha of rice more sustainable than 2 ha of selectively managed hardwood extraction? The only thing it [the rice] sustains is poverty" (Anonymous personal communication). Although there is currently, in a few instances, only minimal infrastructure in place to regulate, monitor, and support sustainable selective logging, and there is proven scope for illegal logging, many residents press for help with the development of an effective program of sustainable harvest and regulation.

\section{Scope and limitations}

This preliminary study cannot claim to extrapolate results directly to all forest lands in the CMER, nor is that our intent. Additionally, the data and results do not represent all of the active rubber trail extractive forests in the CMER. However, in 
Table 8. The 10 most dominant species found along rubber trails, by frequency. $N=84$ plots.

\begin{tabular}{cc}
\hline \hline Community A & Community B \\
\hline Tetragastris altissimi (51) & Tetragastris altissimi (42) \\
Siparuna $\mathrm{sp.}$ (38) & Siparuna sp. (27) \\
Pausandra trianae (22) & Protium rhynchophyllum (21) \\
Neea parviflora (18) & Brosimum guianense (21) \\
Maquira sclerophylla (18) & Maquira sclerophylla (19) \\
Brosimum guianense (16) & Hevea brasiliensis (18) \\
Calycophyllum acreanum (15) & Bertholetia excelsa (15) \\
Hevea brasiliensis (14) & Neea sp. (12) \\
Talisia sp. (12) & Pausandra trianae (12) \\
Bertholetia excelsa $(11)$ & Sclerolobium sp. (12) \\
\hline
\end{tabular}

comparing the two sites, we seek to demonstrate the key elements that drive the differential impact on forest cover, forest structure, and tree species biodiversity in these two communities to make the case and prepare the basis for a more comprehensive study across several communities in this and other reserves. According to experimental criteria, to draw definitive conclusions from the inventory data at community level in this type of study, the ideal research design would include a comparison based on several communities of each type in which the sample plot data were merged to represent the whole community. Alternatively, a study could compare data on the forest structure and tree species composition before and after divergent livelihood and land-use changes among various communities within the CMER. At the time of this study, there were no baseline data in this area for the variables in the forest inventory. There are now good baseline data at the household and community level for social and land-use variables and some forest variables, which will provide the basis for future comparisons. The data from this forest inventory in two communities now constitute a baseline for future comparisons in these two sites. However, the requirements were prohibitive for a preliminary study of this type, with landholdings of this size, in terms of time, effort, and financial resources necessary for multiple community inventories of forest structure and species composition.

The CMER has both the maintenance of old-growth forest and biodiversity preservation as part of its conservation goals. We addressed parts of both goals. Our satellite imagery analysis, however, did not incorporate adjustments in deforestation rates to account for secondary succession, nor did it address edge effects and fragmentation. The latter are known to cause vulnerability to drought and fire, as well as changes in forest structure and composition, including impacts on wildlife (Skole and Tucker 1993, Laurance et al. 2000, Wu et al. 2000). Given flora-fauna relationships, it is apparent that overhunting could also affect the overall forest composition and structure. However, our study was restricted to the rubber tappers' defined forest-use trails.

Our conclusions from forest inventories in rubber trail forests and related household and community interviews in two communities cannot be extrapolated directly to the larger forest beyond 
Table 9. Characteristics of commercial tree species and Brazil-nut trees $\dagger$ present in 42 sample plots in the two communities. The total area of the sample plots is 1.05 ha. Mean (SD).

\begin{tabular}{|c|c|c|}
\hline Variable & $\begin{array}{l}\text { Community A } \\
\text { (trees/1.05 ha) }\end{array}$ & $\begin{array}{l}\text { Community B } \\
\text { (trees/1.05 ha) }\end{array}$ \\
\hline $\begin{array}{l}\text { Number of commercial species present out of the top } 30 \text { most important } \\
\text { commercial species in Acre }\end{array}$ & 27 & 23 \\
\hline Total number of commercial stems present ( $\%$ of total stems observed) & $123(19.0)$ & $152(27.7)$ \\
\hline $\begin{array}{l}\text { Number of commercial stems of commercial size } \ddagger \text { ( } \% \text { of all commercial } \\
\text { stems) }\end{array}$ & $30(24.4)$ & $16(10.5)$ \\
\hline Number of Brazil-nut trees present & 11 & 15 \\
\hline Brazil-nut trees of commercial size $\ddagger$ ( $\%$ of Brazil-nut trees) & $9(82.0)$ & $10(66.0)$ \\
\hline Number of old-growth Brazil-nut trees§ (\% of Brazil-nut trees) & $6(55.0)$ & $2(13.0)$ \\
\hline
\end{tabular}

$\dagger$ The Brazil-nut tree is a federally protected species, but is sometimes used in local construction. $\ddagger$ Diameter at breast height $>50 \mathrm{~cm}$.

$\S$ Diameter at breast height $>100 \mathrm{~cm}$.

these extractive units. However, the rubber trail forests covered by the inventory are the most accessible and intensively used forest units in the larger household forest lands. Furthermore, the larger forest is needed to make the creation of the trails possible, and the rubber trail forests help to guarantee the maintenance of the larger forest matrix. Likewise, the results from these two communities are preliminary in nature and cannot be extrapolated directly to all rubber trail forests in the CMER and all extractivist and cattle-focused communities in the region. The results of our preliminary study, however, do indicate differential livelihood and land-use impacts on forest cover, structure, and composition, which is relevant to the future use, management, and condition of the forest as a whole. We have provided a clear rationale, as well as indications for the formulation and design of a larger research study across several communities of each type of livelihood strategy within and beyond the CMER.

Extractivism encompasses a variety of nontimber forest products, plus hunting and timber extraction, with specific and interlinked ecological impacts.
Many of the differences that we found can be explained by timber extraction and hunting practices. Overharvesting of nontimber forest products can also have negative ecological impacts, particularly on avian species (Moegenburg and Levey 2002), with consequential effects on the recruitment and diversity of fruiting plants (Cardoso da Silva and Tabarelli 2000). Further studies are needed regarding the specific effects of various types of NTFP and dominant production activities, as well as the integrated effects of multiple land-use activities and landscape patterns on forest structure and composition.

\section{CONCLUSION}

Our results suggest that the dominant livelihood strategies and associated mix of land-use practices pursued by communities in the CMER, i.e., either NTFP or cattle production, may lead to different performances relative to the environmental mission of the reserve. The cattle-oriented seringal better preserved the structure and diversity of the remaining rubber trail forests, whereas the NTFP- 
oriented seringal preserved proportionately more forest from clearing. This finding raises important concerns about the measures and means of monitoring the performance goals of both the CMER and Federal Extractive Reserves.

Our results also indicate that the type and scale of analysis matters in assessing conservation areas. Remote-sensing analysis exposes the consequences of cattle production: more cleared mature forests, higher rates of deforestation, and a landscape with larger amounts of open land and secondary vegetation. Field inventories and household surveys reveal that the consequences of some extractivist activities negatively affect forest structure and diversity within the rubber trail forests of the mainly extractive community relative to the livestockoriented community.

In both cases, problems with deforestation, as well as changes in forest structure and tree species composition, might well be addressed by infrastructure for marketing, regulation, and monitoring of selective logging, as opposed to the current prohibition of logging throughout the CMER and varying degrees of prohibition of cattle and promotion of food and cash cropping, depending on the community. Serious concerns remain about the feasibility of regulating selective tree harvesting for valuable hardwoods in this context. However, the current parallel trends toward deforestation and forest impoverishment exhibited in the cattle- and NTFP-focused study communities do not seem desirable or sustainable. Fortunately, the reserve managers have begun planning with communities for selective hardwood extraction within the CMER. Research regarding cattle ranching within the CMER will inform planning decisions by development agencies and local communities (Gomes 2001, 2009). Programs such as ProAmbiente recognize that there is no quick fix for sustainable development in the region and encourage multiple-use strategies based on individual and community preferences. Instead of categorical prohibitions regarding land use, conservation goals would be better served if standards were couched in terms of performance criteria that correspond to ecological and livelihood outcomes such as forest cover, volume, diversity, and adequacy of seasonal income for routine and emergency expenses for specific mixed land-use systems.
Responses to this article can be read online at: http://www.ecologyandsociety.org/voll4/iss2/art29/ responses/

\section{Acknowledgments:}

This research was funded by a Fulbright-Hays Doctoral Dissertation Research Abroad Fellowship from the U.S. Department of Education. We thank Evandro Ferreira from the Parque Zoobotanico at the Federal University of Acre for discussions on methodology, botanical experts Antonio Jose Barreto dos Santos and Edilson Consuelo de Oliveira for assistance in the field, the Group for Research and Extension in Agroforestry Systems in Acre (PESACRE) for technical support, and Valério Gomes and Thomas Ludewigs for research support. We are also grateful to Luis Malaret for assistance with biodiversity software, analyses, and statistical tests, and to Ron Eastman and Robert Benfer for statistical consultation. Special thanks to B. L. Turner II, John Rogan, and Marianne Schmink for many helpful comments during research design and manuscript preparation.

\section{LITERATURE CITED}

Alechandre da Rocha, A. 2001. Análise do transecto-trilha: uma abordagem rápida e de baixo custo para avaliar espécies vegetais em florestas tropicais. Thesis. Universidade Federal do Acre, Rio Branco, Brazil. Available online at: http://www .ufac.br/ensino/mestrado/mest ecologia/dissertacoes/ AndreaSilvaAlanche.pdf

Allegretti, M. H. 1990. Extractive reserves: an alternative for reconciling development and environmental conservation in Amazonia. Pages 252-264 in A. B. Anderson, editor. Alternatives to deforestation: steps toward sustainable use of the Amazon rain forest. Columbia University Press, New York, New York, USA.

Ankerson, T., and G. Barnes. 2004. Inside the polygon: emerging community tenure systems and forest resource extraction. Pages 156-177 in D. J. Zarin, J. R. R. Alavalapati, F. E. Putz, and M. Schmink, editors. Working forests in the neotropics: conservation through sustainable management? Columbia University Press, New York, New York, USA. 
Asquith, N. M., J. Terborgh, A. E. Arnold, and C. M. Riveros. 1999. The fruits the agouti ate: Hymenaea courbaril seed fate when its disperser is absent. Journal of Tropical Ecology 15(2):229-235.

Barreto, P., E. Arima, and M. Brito. 2005. Cattle ranching and challenges for environmental conservation in the Amazon. State of the Amazon, Number 5. Imazon, Belém, Brazil. Available online at: http://www.imazon.org.br/novo2008/arquivosdb /141708ea 5e.pdf.

Barreto, P., C. Souza, Jr., R. Noguerón, A. Anderson, R. Salamão, and J. Wiles. 2006. Pressão humana na floresta Amazônica brasileira. World Resources Institute \& Imazon, Belém, Brazil. Available online at: http://www.imazon.org. br/pdf/PressaoHumanaPortugues.pdf.

Berkes, F. 2008. Sacred ecology. Second edition. Routledge, New York, New York, USA.

Berkes, F., and T. Adhikari. 2006. Development and conservation: indigenous businesses and the UNDP Equator Initiative. International Journal of Entrepreneurship and Small Business 3(6):671-690.

Berkes, F., and C. Folke, editors. 1998. Linking social and ecological systems: management practices and social mechanisms for building resilience. Cambridge University Press, Cambridge, UK.

Berkes, F., and C. Folke. 2002. Back to the future: ecosystem dynamics and local knowledge. Pages 121-146 in L. H. Gunderson and C. S. Holling, editors. Panarchy: understanding transformations in human and natural systems. Island Press, Washington, D.C., USA.

Brianezi, T. 2005. Fogo na Reserva Chico Mendes está sob controle, mas ainda há risco, diz represnete do Ibama. Agência Brasil. Ambiente Brasil, Brazil. [online] URL: http://noticias.ambientebrasil.com.br/ noticia/?id=21113.

Browder, J. O. 1992. The limits of extractivism: tropical forest strategies beyond extractive reserves. BioScience 42(3):174-182.

Bruner, A. G., R. E. Gullison, R. E. Rice, and G. A. B da Fonesca. 2001. Effectiveness of parks in protecting tropical biodiversity. Science 291 (5501):125-128.

Buckland, S. T., A. E. Magurran, R. E. Green, and R. M. Fewster. 2005. Monitoring change in biodiversity through composite indices. Philosophical Transactions of the Royal Society B: Biological Sciences 360:243-254.

Cardoso da Silva, J. M., and M. Tabarelli. 2000.

Tree species impoverishment and the future flora of the Atlantic forest of northeast Brazil. Nature 404 (6773):72-75.

Castillo, A., and V. M. Toledo. 2001. Applying ecology in the third world: the case of Mexico. BioScience 50:66-76.

Carneiro da Cunha, M., and M. Barbosa de Almeida, editors. A. J. Cardoso. 2002. Enciclopédia da floresta. Companhia das Letras, São Paulo, Brazil.

Denevan, W. M. 1992. The pristine myth: the landscape of the Americas in 1492. Annals of the Association of American Geographers 82:369-385.

Diversitas. 2002. Diversitas science plan: international program of biodiversity science. Diversitas, Paris, France. Available online at: http:/ /www.diversitas-international.org/docs/diversitas/ diversitassp.pdf.

Elia, C. 2005. Tem boi na linha. O Eco 2 October. [online] URL: http://www.oeco.com.br/reportagens/37reportagens/1342-oeco 14086.

EMBRAPA. 2000. List of forest species in Acre. Empresa Brasileira de Pesquisa Agropecuária, Rio Branco, Brazil.

Euler, A. M. C. 2006. A vegetation ecological study of floristic and structural composition of a tropical rainforest in Antimary State Forest, Acre, Brazil. Dissertation. Yokohama National University, Yokohama, Japan.

Fearnside, P. M. 1990. Predominant land uses in Brazilian Amazonia. Pages 233-251 in A. B. Anderson, editor. Alternatives to deforestation: steps toward sustainable use of the Amazon rain forest. Columbia University Press, New York, New York, USA. 
Feitosa, M. L. 1995. Chico Mendes Extractive Reserve. Pages 69-76 in M. Ruiz Murrieta and R. Pinzón Rueda, editors. Extractive reserves. IUCN, Gland, Switzerland.

Ferraz, G., G. J. Russell, P. C. Stouffer, R. O. Bierregaard, Jr., S. L. Pimm, and T. E. Lovejoy. 2003. Rates of species loss from Amazonian forest fragments. Proceedings of the National Academy of Science 100(24):14069-14073.

FETACRE. 2003. ProAmbiente: plano de desenvolvimento. Federação dos Trabalhadores Rurais do Acre, Rio Branco, Brazil.

Glaser, B., and W. I. Woods, editors. 2004. Amazonian dark earths: explorations in space and time. Springer, Berlin, Germany.

Gomes, C. V. A. 2001. Dynamics of land use in an Amazonian extractive reserve: the case of the Chico Mendes Extractive Reserve in Acre, Brazil. Thesis. University of Florida, Gainesville, Florida, USA.

Gomes, C. V. A. 2009. Twenty years after Chico Mendes: the evolution of Amazonian extractive reserves system and small-scale cattle ranching in the Chico Mendes Extractive Reserve, Acre, Brazil. Dissertation, University of Florida, Gainesville, Florida, USA.

Governo do Estado do Acre. 2000. Zoneamento ecológico-econômico do estado do Acre. SECTMA/ Governo do Estado do Acre, Rio Branco, Brazil.

Green, G. 2001. Radiometric calibration for LANDSAT scene using CPF calibration. CIPEC, Indiana University, Bloomington, Indiana, USA.

Groom, M. J., G. K. Meefe, and C. R. Carroll. 2006. Principles of conservation biology. Third edition. Sinauer, Sunderland, Massachusetts, USA.

Hecht, S., and A. Cockburn. 1990. The fate of the forest: developers, destroyers, and defenders of the Amazon. Reprint. HarperCollins, New York, New York, USA.

Homma, A. K. O. 1993. Extrativismo vegetal na Amazônia: limites e oportunidades. Embrapa-SPI, Brasília, Brazil.
IBAMA. 2003. Reserva Extrativista Chico Mendes: plano de utilização. Instituto Brasileiro do Meio Ambiente e dos Recursos Naturais Renováveis, Brasília, Brazil. [online] URL: http:// www.ibama.gov.br/resex/cmendes/plano.htm.

International Forestry Resources and Institutions. 1998. Field manual, version 8.0. Indiana University, Bloomington, Indiana, USA.

Instituto Nacional de Pesquisas Espacias. 2005. Deforestation rates in the Brazilian Amazon. Instituto Nacional de Pesquisas Espacias, São José dos Campos, São Paulo, Brazil.

Kageyama, P., D. Caron, F. Gandara, K. Martins, L. H. de Oliveira Wadt, C. M. B. de Lacerda, N. Terezinha Boufleuer, L. Arruda Ribas, A. M. Moreno, and E. M. Ferraz. 2004. Genetic and ecological aspects of nonwood forest product exploitation in two western Amazonian settlements. Pages 149-166 in B. Vinceti, W. Amaral, and B. Meilleur, editors. Challenges in managing forest genetic resources for livelihoods. Biodiversity International, Rome, Italy.

Kainer, K. A., M. Schmink, A. C. P. Leite, and M. J. da Silva Fadell. 2003. Experiments in forestbased development in western Amazonia. Society and Natural Resources 16(10):869-886.

Laurance, W. F., H. L. Vasconcelos, and T. E. Lovejoy. 2000. Forest fragmentation in the Amazon: implications for wildlife conservation. Orxy 34(1):39-45.

Margoluis, R., and N. Salafsky. 1998. Measures of success: designing, managing, and monitoring conservation and development projects. Island Press, Washington, D.C., USA.

Magurran, A. E. 2004. Measuring biological diversity. Blackwell, Malden, Massachusetts, USA.

McAleece, N. 1997. Biodiversity professional software. Version 2. The Natural History Museum and Scottish Association for Marine Science, Dunbeg, UK.

Minzenberg, E. 2005. Hunting and household in PDS São Salvador, Acre, Brazil. Dissertation. University of Florida, Gainesville, Florida, USA. 
Ministério do Meio Ambiente. 2004. SNUC: sistema nacional de unidades de conservação da natureza. Sixth edition. Ministério do Meio Ambiente, Brasília, Brazil. Available online at: htt p://www.ecosocialnet.com/legislacao/SNUC.pdf.

Moegenburg, S. M., and D. J. Levey. 2002. Prospects for conserving biodiversity in Amazonian extractive reserves. Ecology Letters 5(3):320-324.

Moran, E. F., and E. Brondizio. 1998. Land-use change after deforestation in Amazonia. Pages 94-120 in D. M. Liverman, E. F. Moran, R. R. Rindfuss, and P.C.Stern, editors. People and pixels: linking remote sensing and social science. National Academy Press, Washington, D.C., USA.

Mori, S. A., B. M. Boom, A. M. Carvalho, and T. S. dos Santos. 1983. Southern Bahian moist forest. Botanical Review 49(2):155-232.

Naughton-Treves, L., M. B. Holland, and K. Brandon. 2005. The role of protected areas in conserving biodiversity and sustaining local livelihoods. Annual Review of Environment and Resources 30:219-252.

Nepstad, D. C., S. Schwartzman, B. Bamberger, M. Santilli, D. Ray, P. Schlesinger, P. Lefebvre, A. Alencar, E. Prinz, G. Fisk, and A. Rolla. 2006. Conservation areas stop forest clearing. Conservation Biology 20(1):65-73.

Oliveira, M. V. N., and H. Sant'anna. 2003. Inventario florestal $e$ avaliação do avanço do desmatamento no projeto de colonização Pedro Peixoto. Empresa Brasileira de Pesquisa Agropecuária, Rio Branco, Brazil.

Pacheco, P. B. 2005. Populist and capitalist frontiers in the Amazon: diverging dynamics of agrarian and land-use change. Dissertation. Clark University, Worcester, Massachusetts, USA.

Pinard, M. 1993. Impacts of stem harvesting on populations of Iriartea deltoidea (Palmae) in an extractive reserve in Acre, Brazil. Biotropica 25 (1):2-14.

RadamBrasil. 1976. Folha SC 19 Rio Branco: geologia, geomorfologia, pedologia, vegetacoe e uso potencial da terra. Governo do Brasil, Rio de Janeiro, Brazil.
Ruiz Murrieta, M., and R. Pinzón Rueda, editors. 1995. Extractive reserves. IUCN, Gland, Switzerland.

Sassagawa, H. S. Y. 1999. Técnicas de sensoriamento remoto e sistema de informação geográficas (SIG) para o estudo da ocupação do espaço fisico e dos tipos florestais da Reserva Extrativista Chico Mendes, estado do Acre. Thesis. Institudo Nacional de Pesquisas Espaciais, São José dos Campos, Brazil.

Schmink, M., and C. H. Wood. 1992. Contested frontiers in Amazonia. Columbia University Press, New York, New York, USA.

Sears, R. R., C. Padoch, and M. Pinedo-Vasquez. 2007. Amazon forestry transformed: integrating knowledge for smallholder timber management in eastern Brazil. Human Ecology 35(6):697-707.

Silvius, K. M., and J. M. V. Fragoso. 2003. Redrumped agouti (Dasyprocta leporina) home range use in an Amazonian forest: implications for the aggregated distribution of forest trees. Biotropica 35(1):74-83.

Skole, D., and C. Tucker. 1993. Tropical deforestation and habitat fragmentation in the Amazon: satellite data from 1978 to 1988 . Science 260:1905-1910.

Stone, S. S. 2003. From tapping to cutting trees: participation and agency in two community-based timber management projects in Acre, Brazil. Dissertation. University of Florida, Gainesville, Florida, USA. Available online at: http://purl.fcla.e du/fcla/etd/UFE0002421.

Terborgh, J. 1999. Requiem for nature. Island Press, Washington, D.C., USA.

Tucker, C. M., and J. Southworth. 2005. Process of forest change at the local and landscape levels in Honduras and Guatemala. Pages 253-277 in E. F. Moran and E. Ostrom, editors. Seeing the forest and the trees: human-environment interactions in forest ecosystems. MIT Press, Cambridge, Massachusetts, USA.

Uhl, C., P. Barreto, A. Veríssimo, E. Vidal, P. Amaral, A. C. Barros, C. Souza, Jr., J. Johns, and J. Gerwing. 1997. Natural resource management in the Brazilian Amazon. BioScience 47:160-168. 
Vadjunec, J. M. 2007. The role of institutions in land-use/cover change in the Chico Mendes Extractive Reserve system, Acre, Brazil. Dissertation. Clark University, Worcester, Massachusetts, USA.

Vadjunec, J. M., C. V. Gomes, and T. Ludewigs. In press. Land-use/cover change among rubber tappers in the Chico Mendes Extractive Reserve, Acre, Brazil. Journal of Land-Change Science.

Veríssimo, A., M. A. Cochrane, C. Souza, Jr., and R. Salomão. 2002. Priority areas for establishing national forests in the Brazilian Amazon. Conservation Ecology 6(1): 4. [online] URL: http:/ /www.consecol.org/vol6/iss1/art4/.

Viana, J. 2004. Foreword. Pages xiii-xvi in D. J. Zarin, J. R. R. Alavalapati, F. E. Putz, and M. Schmink, editors. Working forests in the neotropics: conservation through sustainable management? Columbia University Press, New York, New York, USA.

West, P. W. 2004. Tree and forest measurement. Springer, New York, New York, USA.

Wu, X. B., T. L. Thurow, and S. G. Whisenant. 2000. Fragmentation and changes in hydrologic function of tiger bush landscapes, south-west Niger. Journal of Ecology 88(5):790-800. 
Appendix 1. List of Identified Species' Popular and Scientific Names.

Please click here to download file 'appendixl.doc'. 